\title{
Vegetative Indicators of sour cherry cultivars and resistant clons
}

\author{
Vaszily, B. \\ Research and Extension Centre for Fruit Growing \\ Vadastag 2, H-4244 Ujfeherto, Hungary
}

\begin{abstract}
Summary: Sour cherry is a hungaricum. Hungary has several excellent and self fertile sour cherry cultivars. Hungarian sour cherries have a name for fruit quality and they are suitable for fresh consumption. Today breeding is focused not only on fruit quality, but also on disease resistance. The new, investigated cultivars have these characteristics too. But growth characteristics are also very important because they contribute to successful production. The vegetative and generative properties of the cultivars are different. If a cultivar is very productive, the ignorance of cultivar-specific pruning may result in the decrease in tree condition and fruit quality. The properties of producing fruiting wood greatly determine the renewal capabilities of cultivars. Knowing these properties is essential in case of sour cherries, the fruit species that requires a lot of sunlight and tends to produce bare wood. The research of candidate cultivars until now focused on fruit quality. Our aim was to investigate the vegetative characteristics of the resistant 'bosnyák' cultivar group in detail, defining the growth characteristics of these cultivars.
\end{abstract}

Keywords: sour cherry cultivars, resistant cultivars, pruning, growth characteristics, shoots

\section{Introduction}

Sour cherry trees have specific growth characteristic. The different aged woods are bald. The inside parts of the canopy are inactive, fruits and shoots can be found on the periphery of the trees (Szentpéteri et al., 2006). The balding dynamics of sour cherries is faster, vitality differences resulting from polarity (shooting, sprouting, going bald) are stronger than in case of sweet cherries (Gonda, 2010). The regeneration can be enhanced by the use of vigorous Prunus mahaleb L. rootstock (Gonda et al., 2005).

In some years, due to the factors promoting stronger shoot growth (excessive pruning, nitrogen, a lot of rain, etc.) the sour cherry trees don't develop flower buds. In this case shoots provide bearing wood (Gonda, 2010).

Nowadays pruning is done during the summer period; if carried out properly - timing and way of pruning in relation to the conditions of trees - the ensuing winter pruning may become unnecessary (Gonda, 2003).

By the results of Szentpéteri et al. (2006) summer pruned sour cherry trees produce the most growth point and new shoot location is the best. Summer pruning can bring spectacular results in better insolation inside the canopy. Summer pruning stimulate regeneration characteristics (GONDA, 2010).

Optimal condition of trees gives optimal shooting. Optimal tree condition can be reached with vigorous rootstock, proper pruning and pest control (Holb et al., 2005).

Balding of elder wood parts are typical of unpruned and moderately pruned trees. Long shoots produce small amount of laterals shoots or shoot buds don't sprout, that is came bald (Göndör, 2003). Therefore, the two-year-old parts are already passive and new shoots are only produced from terminal buds (Szentpéteri et al., 2006).

Unpruning results in fast failure of sour cherry trees. Being familiar with the fruit bearing characteristics of the cultivars and with the age distribution of the fruiting wood can unsure regular high yields (Gonda, 2010).

\section{Materials and methods}

The experiments were set up in Debrecen-Pallag at the Experimental Farm of Horticulture and Regional Research Centre of University of Debrecen, and at the Research and Extension Centre for Fruit Growing in Újfehértó in autumn 2013.

The investigated cultivars and parameters of orchards can be found in Table 1. Due to the ease of understanding we indicate with (1) the 'Újfehértói fürtös' cultivar in Pallag and with (2) the trees of the same cultivar planted in Újfehértó. This cultivar is the control cultivar.

The investigations had been performed in the autumn of $2013,3-5$ trees by cultivars. The growth characteristics measured: trunk circumference, first-order branch cross section area, number and length of the total shoots formed. We measured individually the length of the 2-3-4-5 year old wood, and on these parts the number and length of shoots and place of formation (from lateral or terminal buds). Specific values of total shoot length per first-order branch cross section area and total shoot length per branch length was also calculated. 
Table 1: Parameters of the investigated cultivars and orchards

(Pallag and Újfehértó, 2013)

\begin{tabular}{|c|c|c|c|c|c|c|}
\hline Site of orchards & $\begin{array}{c}\text { Sour cherry } \\
\text { cultivar }\end{array}$ & Rootstock & Time of planting & $\begin{array}{r}\text { Planting } \\
\text { distance }\end{array}$ & Canopy form & Pruning \\
\hline \multirow{4}{*}{ Újfehértó } & VN-1 ॐ0 & 'Cema' (C500) & 2005 autumn & $5 \mathrm{~m} \times 3 \mathrm{~m}$ & \multirow{11}{*}{$\begin{array}{l}\text { éééééééééééé } \\
\text { free spindle }\end{array}$} & no \\
\hline & VN-4 ॐँ & 'Cema' (C500) & 2005 autumn & $5 \mathrm{~m} \times 3 \mathrm{~m}$ & & no \\
\hline & Horkai ॐँ & sucker & 2008 spring & $5 \mathrm{~m} \times 3 \mathrm{~m}$ & & no \\
\hline & \begin{tabular}{|l} 
'Újfehértói fürtös' \\
(2)
\end{tabular} & Prunus avium $L$. & 1999 spring & $5 \mathrm{~m} \times 3 \mathrm{~m}$ & & No/volume limiting \\
\hline \multirow{7}{*}{ Pallag } & Csengődi 1 ऊँ & \multirow{7}{*}{ Cerasus mahaleb $L$. } & 2005 spring & $5 \mathrm{~m} \times 2 \mathrm{~m}$ & & yearly winter/summer \\
\hline & Csengődi 2 ॐ & & 2005 spring & $5 \mathrm{~m} \times 2 \mathrm{~m}$ & & yearly winter/summer \\
\hline & Csengődi 4 ॐ & & 2005 spring & $5 \mathrm{~m} \times 2 \mathrm{~m}$ & & yearly winter/summer \\
\hline & Csengődi 8 ॐ & & 2005 spring & $5 \mathrm{~m} \times 2 \mathrm{~m}$ & & yearly winter/summer \\
\hline & Csengődi 12 ॐ & & 2005 spring & $5 \mathrm{~m} \times 2 \mathrm{~m}$ & & yearly winter/summer \\
\hline & \begin{tabular}{|l} 
'Újfehértói fürtös' \\
(1)
\end{tabular} & & 2005 spring & $5 \mathrm{~m} \times 2 \mathrm{~m}$ & & yearly winter/summer \\
\hline & 'Kántorjánosi' & & 2003 spring & $5 \mathrm{~m} \times 2 \mathrm{~m}$ & & yearly winter/summer \\
\hline
\end{tabular}

Notes: ${ }^{\circ}$ resistant cultivar, (1) trees in Pallag, (2) trees in Újfehértó

\section{Results}

'Újfehértói fürtös' (1) had the longest specific total shoot length (Table 2.) and the highest number of shoots. However, the 'Újfehértói fürtös' (2) trees in Újfehértó had the lowest specific values. The reason for this (same cultivars) is probably the different pruning.

Table 2: Specific vegetative indicators of sour cherry cultivars (Pallag and Újfehértó, 2013)

\begin{tabular}{|c|c|c|c|}
\hline Sour cherry cultivar & $\begin{array}{c}\text { Average } \\
\text { shoot length } \\
\text { (cm) }\end{array}$ & $\begin{array}{c}\text { Total shoot } \\
\text { length }(\mathrm{cm}) / \\
\text { branch cross } \\
\text { section area } \\
\mathrm{cm}^{2}\end{array}$ & $\begin{array}{c}\text { Total shoot } \\
\text { number (pc)/ } \\
\text { branch cross } \\
\text { section area } \\
\mathrm{cm}^{2}\end{array}$ \\
\hline VN-1 ॐँ & 8.50 & 73.60 & 8.70 \\
\hline ‘Újfehértói fürtös’ (2) & 9.80 & 57.60 & 5.90 \\
\hline Horkai ॐ0 & 12.40 & 105.70 & 8.50 \\
\hline VN-4 ॐ & 12.60 & 147.20 & 11.70 \\
\hline Csengödi 2 ॐँ & 25.60 & 142.80 & 5.60 \\
\hline Csengődi 8 ॐँ & 26.20 & 151.40 & 5.80 \\
\hline Csengődi 12 ॐँ & 26.50 & 182.90 & 6.90 \\
\hline ‘Újfehértói fürtös' (1) & 29.70 & 306.90 & 10.30 \\
\hline Csengődi 1 ॐँ & 30.60 & 235.00 & 7.70 \\
\hline ‘Kántorjánosi' & 33.70 & 276.80 & 8.20 \\
\hline Csengődi 4 & 38.10 & 218.80 & 5.70 \\
\hline
\end{tabular}

Notes: ॐँ resistant cultivar, (1) trees in Pallag, (2) trees in Újfehértó

VN-4 clone had the maximum of the specific shoot pieces, Csengődi 2 had minimum. 'Kántorjánosi' and Csengődi 4 cultivars had the longest specific shoots and $\mathrm{VN}-1$ clone had the minimum.

We classified the shoots according to their length in 3 categories (Table 3.). All Csengődi cultivar, 'Kántorjánosi' and 'Újfehértói fürtös' (1) in Pallag didn't produce much short $(1-5 \mathrm{~cm}$ and $5-20 \mathrm{~cm})$ shoots. All these cultivars were planted in Pallag.

Table 3: Frequency distribution of shoots of cultivars in different size categories (Pallag and Újfehértó, 2013)

\begin{tabular}{|c|c|c|c|c|}
\hline \multirow{2}{*}{ Cultivars } & \multicolumn{4}{|c|}{ frequency distribution (\%) } \\
\hline & $1-5 \mathrm{~cm}$ & $6-20 \mathrm{~cm}$ & $21-40 \mathrm{~cm}$ & $41 \mathrm{~cm}<$ \\
\hline VN-1 ॐँ & 38.46 & 55.13 & 6.41 & 0.00 \\
\hline VN-4 ॐ & 14.77 & 71.59 & 10.23 & 3.41 \\
\hline ‘Újfehértói fürtös' (2) & 25.71 & 68.57 & 5.71 & 0.00 \\
\hline Horkai ॐँ & 10.00 & 78.57 & 7.14 & 4.29 \\
\hline Csengődi 1 ॐँ & 0.00 & 28.45 & 44.83 & 26.72 \\
\hline Csengődi 2 ॐँ & 0.00 & 40.51 & 39.24 & 20.25 \\
\hline Csengődi 4 ॐँ & 0.00 & 10.99 & 39.56 & 49.45 \\
\hline Csengődi 12 ॐ & 0.00 & 34.48 & 50.57 & 14.94 \\
\hline Csengődi 8 ॐँ & 0.00 & 27.27 & 61.82 & 10.91 \\
\hline 'Újfehértói fürtös' (1) & 0.00 & 40.96 & 34.94 & 24.10 \\
\hline 'Kántorjánosi’ & 0.77 & 30.00 & 43.85 & 25.38 \\
\hline
\end{tabular}

Notes: $ّ$ resistant cultivar, (1) trees in Pallag, (2) trees in Újfehértó

However, VN-1, VN-4, Horkai and 'Újfehértói fürtös'(2) cultivars produced many short shoots.

Csengődi cultivars, 'Kántorjánosi' and 'Újfehértói fürtös (1) had shoots in all categories evenly. These cultivars have optimal growth characteristics.

Csengődi 4 produced the most shoots above $40 \mathrm{~cm}$ and this cultivar also had the largest average shoot length.

VN-1 and 'Újfehértói fürtös' formed the most short shoots $(1-5 \mathrm{~cm})$, the average shoot length was $8-10 \mathrm{~cm}$. Csengödi 1 , 2, 8, 12 and 'Kántorjánosi' have 20-40 cm shoots on a large scale. However, according to the results of SOLTÉSZ (1997), 
short shoots are typical of Csengődi cultivar. It is interesting, that 'Újfehértói fürtös' (1) trees in Pallag did't produce short shoots, but this cultivar planted in Újfehértó formed short shoots on a large scale.

Based on the specific shoot length per branch cross-section area and number of shoots in each size category, we can create the following cultivar groups:

- Long shoots scarcely produced: Csengődi 4

- Short shoots scarcely produced: 'Újfehértói fürtös' (2)

- Medium-sized shoots scarcely produced: Csengődi 1, Csengődi 2, Csengődi 8, Csengődi 12

- Many long shoots produced: no cultivars in this group.

- Many short shoots produced: Horkai, VN-1, VN-4 and 'Újfehértói fürtös' (1)

- Many medium-sized shoots produced: 'Kántorjánosi'.

Regularly pruned trees form significantly longer shoots than not pruned trees (Figure 1.).

The above relationship is confirmed by the values shown in Table 4.

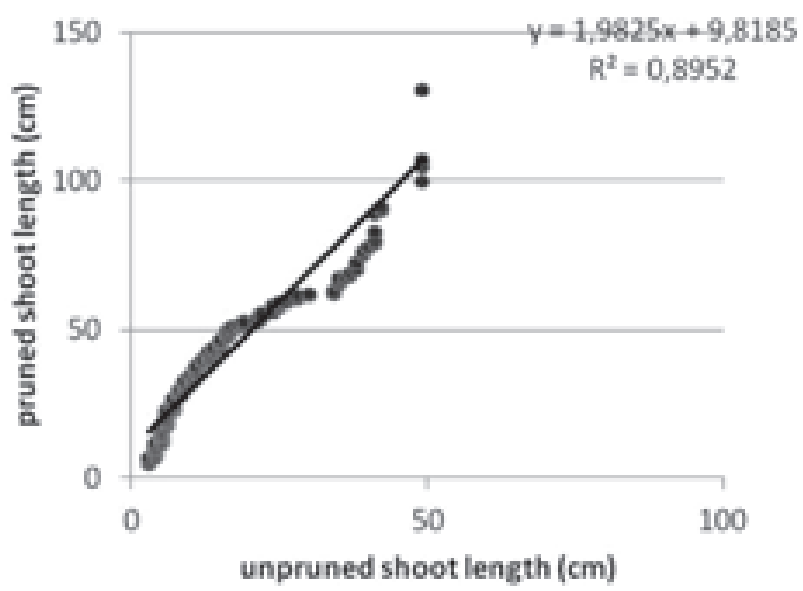

Figure 1. Correlation between shoot length and pruning (Pallag and Újfehértó, 2013)
Table 4: The frequency distribution of shoots on 2-year-old canopy parts of sour cherries depending on growth characteristics (Pallag and Újfehértó, 2013)

\begin{tabular}{|c|c|c|c|}
\hline \multirow[b]{2}{*}{ Cultivars } & \multicolumn{3}{|c|}{ frequency distribution \% } \\
\hline & No sprouting & $\begin{array}{c}\text { Only from } \\
\text { terminal buds }\end{array}$ & More shoots \\
\hline VN-1 ॐ & 35.05 & 57.73 & 7.22 \\
\hline VN-4 ॐ & 41.82 & 29.09 & 29.09 \\
\hline ‘Újfehértói fürtös' (2) & 28.95 & 71.05 & 0.00 \\
\hline Horkai ॐ & 36.84 & 44.74 & 18.42 \\
\hline Csengődi 1 ॐ & 0.00 & 41.94 & 58.06 \\
\hline Csengődi 2 ऊँ & 23.08 & 34.62 & 42.31 \\
\hline Csengődi 4 ऊँ & 0.00 & 26.09 & 73.91 \\
\hline Csengődi 12 ॐ & 0.00 & 60.61 & 39.39 \\
\hline Csengődi 8 ॐँ & 5.56 & 50.00 & 44.44 \\
\hline 'Újfehértói fürtös' (1) & 0.00 & 64.00 & 36.00 \\
\hline 'Kántorjánosi' & 0.00 & 13.04 & 86.96 \\
\hline
\end{tabular}

Notes: ॐ resistant cultivar, (1) trees in Pallag, (2) trees in Újfehértó

We categorized the shoots produced on the most valuable, two-year old wood. VN-1, VN-4, Horkai and 'Újfehértói fürtös' (2) trees had the most two-year old wood that not produced shoots in the year investigated. These cultivars and Csengődi 8, 12, 'Újfehértói fürtös' (1) grew mostly from terminal buds. Most branching on two-year old was observed in trees of 'Kántorjánosi', Csengődi 4, Csengődi 1 cultivars.

Shoots are also formed on different aged wood (2-3-4-5) (Table 5.). This characteristic is very important for the practical grower, as it defines the cultivar's ability for growth and renewal. Knowing the growth characteristics of these parts determine specific pruning strategy and ensure regular high crops with excellent fruit quality.

VN-1, VN-4, Horkai cultivars formed very short shoots on two-year old wood. 'Újfehértói fürtös' (2) trees planted

Table 5: Specific values of sour cherries on different aged canopy parts (Pallag and Újfehértó, 2013)

\begin{tabular}{|c|c|c|c|c|c|c|c|c|c|c|c|c|}
\hline & Age of crown parts & $\begin{array}{c}\text { Csengôdi } \\
1 \text { ऊँ }\end{array}$ & $\begin{array}{c}\text { Csengôdi } \\
2 \text { ॐँ }\end{array}$ & $\begin{array}{c}\text { Csengôdi } \\
4 \text { ॐ }\end{array}$ & $\begin{array}{c}\text { Csengődi } \\
12 ~\end{array}$ & $\begin{array}{c}\text { Csengődi } \\
8 \text { ॐ } \\
\end{array}$ & $\begin{array}{c}\text { 'Újfe- } \\
\text { hértói } \\
\text { fürtös' (1) }\end{array}$ & $\begin{array}{l}\text { 'Kántor- } \\
\text { jánosi' }\end{array}$ & VN-1 ॐ & VN-4 ॐ & $\begin{array}{c}\text { 'Újfe- } \\
\text { hértói } \\
\text { fürtös' (2) }\end{array}$ & Horkai ॐ \\
\hline \multirow{3}{*}{ 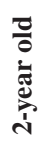 } & shoot number pc/m & 10.94 & 8.85 & 7.31 & 6.65 & 9.63 & 5.54 & 9.31 & 6.52 & 9.95 & 7.91 & 7.59 \\
\hline & shoot length $\mathrm{cm} / \mathrm{m}$ & 325.13 & 222.57 & 274.70 & 169.17 & 248.64 & 155.14 & 299.46 & 47.31 & 112.72 & 75.35 & 82.78 \\
\hline & average shoot length $\mathrm{cm}$ & 29.73 & 25.15 & 37.57 & 25.45 & 25.82 & 28.02 & 32.16 & 7.26 & 11.33 & 9.53 & 10.90 \\
\hline \multirow{3}{*}{ 흥 } & shoot number pc/m & 0.95 & 4.10 & 5.41 & 6.71 & 4.26 & 10.61 & 10.16 & 0.00 & 0.00 & 3.94 & 0.00 \\
\hline & shoot length $\mathrm{cm} / \mathrm{m}$ & 72.38 & 88.52 & 259.46 & 235.37 & 116.49 & 342.45 & 362.03 & 0.00 & 0.00 & 25.20 & 0.00 \\
\hline & average shoot length $\mathrm{cm}$ & 76.00 & 21.60 & 48.00 & 35.09 & 27.38 & 32.27 & 35.63 & 0.00 & 0.00 & 6.40 & 0.00 \\
\hline \multirow{3}{*}{ 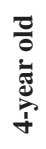 } & shoot number pc/m & 3.30 & 1.60 & 1.64 & 3.33 & 3.03 & 6.41 & 3.33 & 0.00 & 0.00 & 0.00 & 0.00 \\
\hline & shoot length $\mathrm{cm} / \mathrm{m}$ & 128.57 & 35.20 & 59.02 & 120.00 & 127.27 & 141.03 & 150.00 & 0.00 & 0.00 & 0.00 & 0.00 \\
\hline & average shoot length $\mathrm{cm}$ & 39.00 & 22.00 & 36.00 & 36.00 & 42.00 & 22.00 & 45.00 & 0.00 & 0.00 & 0.00 & 0.00 \\
\hline \multirow{3}{*}{ 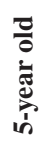 } & shoot number $\mathrm{pc} / \mathrm{m}$ & 0.00 & 2.13 & 4.55 & 4.00 & 0.00 & 0.00 & 0.00 & 0.00 & 0.00 & 2.94 & 0.00 \\
\hline & shoot length $\mathrm{cm} / \mathrm{m}$ & 0.00 & 85.11 & 150.00 & 88.80 & 0.00 & 0.00 & 0.00 & 0.00 & 0.00 & 41.18 & 0.00 \\
\hline & average shoot length $\mathrm{cm}$ & 0.00 & 40.00 & 33.00 & 22.20 & 0.00 & 0.00 & 0.00 & 0.00 & 0.00 & 14.00 & 0.00 \\
\hline
\end{tabular}

Notes: 30 resistant cultivar, (1) trees in Pallag, (2) trees in Újfehértó 
in Újfehértó form low amount of short shoots on 2-3 and 5 year-old wood. Csengődi 1, 8, 'Kántorjánosi' trees develop many shoots on two-year old wood, while 'Újfehértói fürtös' in Pallag formed many shoots on 3-4 year-old wood. Shoots developed on the oldest measured, 5 year-old wood of Csengődi 12, 4, 2 and 'Újfehértói fürtös' (2) trees.

\section{Conclusions}

Distribution and type of bearing wood determines timing and method of pruning. Higher specific shoot length on older wood results in good renewal ability. According to Soltész (1997), the higher the ratio of longer shoots a cultivars has, the stronger and more regular pruning of the trees is necessary. These trees have optimal regeneration/renewal ability. From the renewal point of view, optimal distribution of shoots produced on different aged (2-3-4-5 years) wood would be optimal.

Our study showed significant difference between trees of 'Újfehértói fürtös' planted in Pallag and Újfehértó, that is caused by different pruning. All trees in Pallag were pruned regularly, but in Újfehértó only growth limiting pruning was carried out, and not annually.

Short shoots have weak vitality and age quickly. Many short shoots in canopy cause bald parts. Therefore it is important to ensure long shoots by tree shaping (Soltész, 1997).

According to Szentpéteri et al. (2006) place of the shoot formation is related to the effect of pruning or unpruning. All cultivars planted in Pallag formed more than one shoots. These trees were pruned regularly. Trees in Újfehértó (not pruned annually) formed shoots mostly from terminal buds. If the trees grow only from terminal buds, growth will stop. If the trees have excess floral buds, condition and fruit quality will fail and productivity will decrease.

Our results confirm the statement of Szentpéteri et al. (2006), that 'Kántorjánosi' cultivar has good regeneration ability.
We can conclude, that short and medium-sized shoots are produced on two-year old wood, and medium-sized and long shoots on 3-4-5-year old wood, i.e. elder plant parts produce fewer and longer shoots.

However, further examination of the candidate cultivars is necessary for drawing final and consistent conclusion.

\section{Acknowledgements}

,This research was realized in the frames of TÁMOP 4.2.4. A/2-11-1-2012-0001 „National Excellence Program Elaborating and operating an inland student and researcher personal support system" The project was subsidized by the European Union and co-financed by the European Social Fund."

\section{References}

Gonda, I. (2003): Metszés. [ In: Papp J. (szerk.): Gyümölcstermesztési alapismeretek.] Mezőgazda Kiadó, Budapest. 292-305. p.

Gonda, I. (2010): Csonthéjas gyümölcsfák metszése. DE AMTC KFI, Gonda István Betéti Társaság, Debrecen.

Göndör, J. (2003): Gyümölcstermő növények morfológiája. [In: Papp J. (szerk.): Gyümölcstermesztési alapismeretek.] Mezőgazda Kiadó, Budapest. 78-79. p.

Holb, I., Veisz, J., Abonyi, F. (2005): Meggy és cseresznye komplex ökológiai növényvédelmi technológiája. [In: Holb I. (szerk.): A gyümölcsösök és a szőlő ökológiai növényvédelme.] Mezőgazda Kiadó, Budapest.

Soltész, M. (1997): Integrált gyümölcstermesztés. Mezőgazda Kiadó, Budapest. 626-630. p.

Szentpéteri, T., Király, K., Dani, T., Gonda, I. (2006): Meggyfajták ifjítása és termőrész regeneráció sajátosságainak vizsgálata. Agrártudományi Közlemények, 23: 102-105. 